\title{
In Vitro DNA-Binding, Cleavage Activity with pBR322, Molecular Docking and Antiproliferative Studies of Newly Synthesized Steroidal Imidazolidine Hybrids
}

\author{
Ayaz Mahmood Dar1, 2*, Shamsuzzaman, Mir Shabeer Ahmad² and Manzoor Ahmad Gatoo ${ }^{3}$ \\ ${ }^{1}$ Department of Chemistry, Aligarh Muslim University, Aligarh 202 002, India \\ ${ }^{2}$ Department of Chemistry, Govt Degree College Kulgam 192231, J\&K India \\ ${ }^{3}$ Department of Biochemistry, Jawaharlal Nehru Medical College Aligarh Muslim University, Aligarh 202 002, India
}

\begin{abstract}
New steroidal imidazolidine derivatives (7-9) were synthesized by reacting steroidal thiosemicarbazones (4-6) with ethyl-2-chloroacetate in absolute ethanol. After characterization by spectral and analytical data, the interaction studies of compounds (7-9) with DNA were carried out by UV-vis, luminescence spectroscopy, circular dichroism and gel electrophoresis. The compounds bind to DNA preferentially through electrostatic and hydrophobic interactions with $\mathrm{Kb} ; 2.07 \times 104 \mathrm{M}^{-1}, 2.1 \times 104 \mathrm{M}^{-1}$ and $1.9 \times 104 \mathrm{M}^{-1}$, respectively indicating the higher binding affinity of compound 8 towards DNA. Gel electrophoresis demonstrated that the compound 8 show strong interaction with DNA and during its cleavage activity with pBR322 DNA, it seems to follow the mechanistic pathway, involving singlet oxygen and superoxide anion to generate ROS responsible for initiating DNA strand scission. The docking study suggested the intercalation of imidazolidine moiety of steroid derivative in minor groove of DNA. In MTT assay, compounds 7-9 revealed potential toxicity against different human cancer cells especially compound 8 against A549 cells. Genotoxicity of compounds (7-9) was checked by comet assay. In western blotting, the expressions of relevant apoptotic markers depicted an apoptosis by steroidal imidazolidines in A549 cells.
\end{abstract}

Keywords: Imidazolidine; DNA binding; Cytotoxicity; Genotoxicity; Apoptosis

\section{Introduction}

Synthetic chemistry has gained enormous popularity for its important role in drug discovery over the last few decades. A number of natural products, their semi synthetic analogs and other small molecules have been discovered and screened for their role in the treatment of various diseases such as cancer, diabetes, microbial infections and cardiovascular diseases [1]. However because of the drug tolerance problems, there is always scope for the design and development of new and modified analogs as more efficient drug candidates. This has been done through the rational design and synthesis of receptor based lead molecules which still remains an open area. Natural products have extensively been used as starting tools for the design and synthesis of lead therapeutic scaffolds. Substituted imidazolidine derivatives, an important class of heterocyclic compounds are central substructures of many compounds exhibiting biological and pharmacological properties $[2,3]$. They exhibit a wide range of biological activities such as nitric-oxide synthase inhibition, anti-inflammatory, anti-parasitic, antimicrobial, analgesic, $\alpha$-adrenergic receptor agonist, hypoglycemic, anticonvulsant and potential cyclooxygenase-2 (COX-2) inhibition [4-12].

In molecular biology and drug development, the nucleic acid cleaving agents have attracted extensive attention due to their potential applications [13]. The phosphodiester bonds of DNA are extremely stable and the half-life of DNA for hydrolysis is estimated to be around 200 million years under uncatalyzed physiological conditions [14]. Metal complexes have been widely investigated as cleaving agents of nucleic acids and are found to be reasonably efficient [15], but their use in pharmacy is restricted because of serious issues over the liability and toxicity produced due to free radical generation of some transition metals during the redox processes [16]. To overcome these limitations of liability and toxicity, Scheffer and co-workers [17] put forward the concept of 'metal-free cleaving agents' which are being applied to active phosphodiesters like 'nucleic acid mimic' and RNA. In continuation of our previous work [18] herein, we report the synthesis of new steroidal imidazolidines as metal free DNA binding agents. In order to validate the specific binding mode of the new compounds, a computer aided molecular docking study was carried out. Furthermore, these compounds have also been screened for in vitro cytotoxicity as well as genotoxicity.

\section{Experimental}

\section{Material and methods}

Chemicals were purchased from Merck and Sigma-Aldrich as 'synthesis grade'. Melting points are recorded in degrees Celsius on a Kofler apparatus. The IR spectra were recorded on $\mathrm{KBr}$ pellets with Pye Unicam SP3-100 Spectrophotometer and values are given in $\mathrm{cm}^{-1}$. $1 \mathrm{H}$ and ${ }^{13} \mathrm{C}$ NMR spectra were run in $\mathrm{CDCl}_{3}$ on a JEOL Eclipse $(400$ $\mathrm{MHz}$ ) instrument with TMS as internal standard and values are given in $\mathrm{ppm}(\delta)$. Mass spectra were recorded on a JEOL SX 102/DA-6000 Mass Spectrometer. Thin layer chromatography (TLC) plates were coated with silica gel $G$ and exposed to iodine vapours to check the homogeneity as well as the progress of reaction. Sodium sulphate (anhydrous) was used as a drying agent. Super coiled pBR322 DNA was purchased from GeNei (India) while as double-stranded calf

*Corresponding author: Ayaz Mahmood Dar, Department of Chemistry, Aligarh Muslim University, Aligarh 202 002, India, Tel: +91-9286990247; E-mail: ayazchem09@gmail.com; manzayaz.bh@amu.ac.in

Received July 06, 2015; Accepted October 05, 2015; Published October 12, 2015

Citation: Dar AM, Shamsuzzaman, Ahmad MS, Gatoo MA (2015) In Vitro DNABinding, Cleavage Activity with pbr322, Molecular Docking and Antiproliferative Studies of Newly Synthesized Steroidal Imidazolidine Hybrids. J Biomol Res Ther 4 131. doi:10.4172/2167-7956.1000131

Copyright: (C) 2015 Dar AM, et al. This is an open-access article distributed unde the terms of the Creative Commons Attribution License, which permits unrestricted use, distribution, and reproduction in any medium, provided the original author and source are credited. 
Citation: Dar AM, Shamsuzzaman, Ahmad MS, Gatoo MA (2015) In Vitro DNA-Binding, Cleavage Activity with pbr322, Molecular Docking and Antiproliferative Studies of Newly Synthesized Steroidal Imidazolidine Hybrids. J Biomol Res Ther 4: 131. doi:10.4172/2167-7956.1000131

thymus DNA, purchased from Sigma, was dissolved in a $0.1 \mathrm{M}$ Trisbuffer. The purity of DNA was verified by monitoring the ratio of absorbance at $260 \mathrm{~nm}$ to that at $280 \mathrm{~nm}$, which was in the range 1.8-1.9. The concentration of the DNA was determined spectrophotometrically using $\epsilon_{260}=6600 \mathrm{M}^{-1} \mathrm{~cm}^{-1}$ [19]. The human cancer cell lines used for the test were A545, MCF-7, HeLa, HL-60, SW480, HepG2, HT-29 and A549 and were obtained from National Cancer Institute (NCI), biological testing branch, Federick Research and Development Centre, USA.

\section{General method for the synthesis of steroidal thiosemicarbazones (4-6)}

The steroidal thiosemicarbazones (4-6) were synthesized by a literature method [20] which involves the refluxing of an equimolar solution of steroidal ketones (1-3) and thiosemicarbazide in ethanol in the presence of few drops of $\mathrm{HCl}$ for $5 \mathrm{~h}$. After cooling, the compounds were filtered and recrystallized from methanol.

General method for the synthesis of 5'-acetyl-2'thioxoimidazolidin-4'-one-1-yl-6-amino-5a-cholestane derivatives (7-9)

To a solution of steroidal thiosemicarbazone derivatives (4-6) (1.5 $\mathrm{mmol})$ in absolute ethanol $(20 \mathrm{~mL})$, an equimolar amount of ethyl-2chloroacetoacetate was added. The reaction mixture was refluxed for $3 \mathrm{~h}$. The progress and completion of the reaction was monitored by TLC. After completion of reaction the excess solvent was removed to three fourths of the original volume under reduced pressure. The reaction mixture was then taken in diethyl ether, washed with water and dried over anhydrous sodium sulfate. Evaporation of solvents and recrystallization from methanol afforded respective products (7-9).

3ß-Acetoxy [5'-acetyl-2'-thioxoimidazolidin-4'-one-1-yl]-6amino-5a-cholestane (7)

White powder; yield: $75 \%$. m.p. $143-145^{\circ} \mathrm{C}$; Anal. Calcd for $\mathrm{C}_{34} \mathrm{H}_{53} \mathrm{~N}_{3} \mathrm{O}_{4} \mathrm{~S}$ : C, 68.01, H, 8.86, N, 6.93 found: C, 68.08, H, 8.91, N, 7.0; IR (KBr) $v \mathrm{~cm}^{-1}$ : $3336(\mathrm{NH}), 1714\left(\mathrm{OCOCH}_{3}\right), 1695(\mathrm{C}=\mathrm{O}), 1674$ (CONH), $1643(\mathrm{C}=\mathrm{N}), 1273(\mathrm{C}=\mathrm{S}), 1080(\mathrm{C}-\mathrm{O}), 1025(\mathrm{C}-\mathrm{N}) ;{ }^{1} \mathrm{H}$ NMR (400 MHz, $\left.\mathrm{CDCl}_{3}, \mathrm{ppm}\right): \delta 8.2(\mathrm{~s}, 1 \mathrm{H}, \mathrm{NH}$, exchangeable with $\left.\mathrm{D}_{2} \mathrm{O}\right), 4.43\left(\mathrm{~s}, 1 \mathrm{H}, \mathrm{C}_{5}{ }^{\prime} \mathrm{H}\right), 4.7\left(\mathrm{~m}, 1 \mathrm{H}, \mathrm{C}_{3} \mathrm{a}-\mathrm{H}, \mathrm{W}^{1 / 1} / 2=15 \mathrm{~Hz}\right), 2.03(\mathrm{~s}$, $\left.3 \mathrm{H}, \mathrm{OCOCH}_{3}\right), 1.18\left(\mathrm{~s}, 3 \mathrm{H}, \mathrm{C}_{10}-\mathrm{CH}_{3}\right), 0.70\left(\mathrm{~s}, 3 \mathrm{H}, \mathrm{C}_{13}-\mathrm{CH}_{3}\right), 0.97$ and 0.83 (other methyl protons). ${ }^{13} \mathrm{C}$ NMR $\left(100 \mathrm{MHz}, \mathrm{CDCl}_{3}, \mathrm{ppm}\right): \delta 184$, $173.2,171.6,173.3,155.3,87.2,70,46,44,42,39,35,26,24,22,20,19$, 18; ESI MS: $\mathrm{m} / \mathrm{z} 599\left[\mathrm{M}^{+}.\right]$.

3 $\beta$-Chloro [5'-acetyl-2'-thioxoimidazolidin-4'-one-1-yl]-6amino-5 $\alpha$-cholestane (8)

White powder; yield: $80 \%$. m.p. $132-134^{\circ} \mathrm{C}$; Anal. Calcd for $\mathrm{C}_{32} \mathrm{H}_{50} \mathrm{C}_{1} \mathrm{~N}_{3} \mathrm{O}_{2} \mathrm{~S}: \mathrm{C}, 66.57, \mathrm{H}, 8.64, \mathrm{~N}, 7.17$ found: $\mathrm{C}, 66.69, \mathrm{H}, 8.75, \mathrm{~N}$, 7.29; IR (KBr) $v \mathrm{~cm}^{-1}: 3328(\mathrm{NH}), 1693(\mathrm{C}=\mathrm{O}), 1672(\mathrm{CONH}), 1641$ $(\mathrm{C}=\mathrm{N}), 1269(\mathrm{C}=\mathrm{S}), 1027(\mathrm{C}-\mathrm{N}), 741(\mathrm{C}-\mathrm{Cl}) ;{ }^{1} \mathrm{H}$ NMR $(400 \mathrm{MHz}$, $\left.\mathrm{CDCl}_{3}, \mathrm{ppm}\right): \delta 8.0\left(\mathrm{~s}, 1 \mathrm{H}, \mathrm{NH}\right.$, exchangeable with $\left.\mathrm{D}_{2} \mathrm{O}\right), 4.41(\mathrm{~s}, 1 \mathrm{H}$, $\left.\mathrm{C}_{5}{ }^{\prime} \mathrm{H}\right), 3.9\left(\mathrm{~m}, 1 \mathrm{H}, \mathrm{C}_{3} \mathrm{\alpha}-\mathrm{H}, \mathrm{W}^{1} \frac{1}{2}=17 \mathrm{~Hz}\right), 1.17\left(\mathrm{~s}, 3 \mathrm{H}, \mathrm{C}_{10}-\mathrm{CH}_{3}\right), 0.71$ (s, $\left.3 \mathrm{H}, \mathrm{C}_{13}-\mathrm{CH}_{3}\right), 0.98$ and 0.80 (other methyl protons). ${ }^{13} \mathrm{C}$ NMR (100 $\left.\mathrm{MHz}, \mathrm{CDCl}_{3}, \mathrm{ppm}\right): \delta 185,173.4,171.2,154.6,84.2,50,46,44,42,39$, 35, 26, 24, 22, 20, 19, 18; ESI MS: m/z 575/577 [ $\mathrm{M}^{+}$. $]$.

[5'-Acetyl-2' -thioxoimidazolidin-4'-one-1-yl]-6-amino-5acholestane (9)

Yellow powder; yield: $78 \%$. m.p. $127-129^{\circ} \mathrm{C}$; Anal. Calcd for $\mathrm{C}_{32} \mathrm{H}_{51} \mathrm{~N}_{3} \mathrm{O}_{2} \mathrm{~S}$ : C, 70.86, H, 9.40, N, 7.72 found: C, 70.93, H, 9.49, N,
7.76; IR (KBr) $v \mathrm{~cm}^{-1}: 3327(\mathrm{NH}), 1695(\mathrm{C}=\mathrm{O}), 1671(\mathrm{CONH}), 1640$ $(\mathrm{C}=\mathrm{N}), 1267(\mathrm{C}=\mathrm{S}), 1029(\mathrm{C}-\mathrm{N}) ;{ }^{1} \mathrm{H}$ NMR $\left(400 \mathrm{MHz}, \mathrm{CDCl}_{3}, \mathrm{ppm}\right): \delta$ $7.8\left(\mathrm{~s}, 1 \mathrm{H}, \mathrm{NH}\right.$, exchangeable with $\left.\mathrm{D}_{2} \mathrm{O}\right), 4.42\left(\mathrm{~s}, 1 \mathrm{H}, \mathrm{C}_{5}{ }_{5} \mathrm{H}\right), 1.18(\mathrm{~s}, 3 \mathrm{H}$ $\left.\mathrm{C}_{10}-\mathrm{CH}^{3}\right), 0.73$ (s, $3 \mathrm{H}, \mathrm{C}_{13}-\mathrm{CH}_{3}$ ), 0.97 and 0.80 (other methyl protons); ${ }^{13} \mathrm{C}$ NMR (100 MHz, $\left.\mathrm{CDCl}_{3}, \mathrm{ppm}\right): \delta 183,171.9,170.2,152.6,87.2,46$, $44,42,39,35,26,25,24,22,20,19,18$; ESI MS: $\mathrm{m} / \mathrm{z} 541\left[\mathrm{M}^{+}.\right]$.

\section{DNA binding}

Absorption and emission spectroscopy: The DNA binding experiments of compounds were carried out by using absorption titration and emission spectroscopy [21]. The UV-vis spectra for DNA-steroid interactions were obtained using an Agilent 8453 spectrophotometer while as fluorescence measurements were carried out with a JASCO spectrofluorimeter (FP 6200). Solutions of DNA and steroid were scanned in a $1 \mathrm{~cm}$ quartz cuvette. To eliminate the absorbance of the DNA while measuring the absorption spectra, an equal amount of DNA was added to both the compound solution and the reference solution.

Circular dichroism measurements: Circular dichroism measurements were recorded on a JASCO (J-810) spectropolarimeter by keeping the concentration of DNA constant $\left(5 \times 10^{-5} \mathrm{M}\right)$ while varying the steroid concentration ( $\mathrm{ri}=[$ Compound] $/[\mathrm{DNA}]=\mathrm{ri}=0.8,0.13$, 0.23 ). The optical chamber of the CD spectrometer was deoxygenated with dry nitrogen before use and kept in a nitrogen atmosphere during experiments. All observed CD spectra were corrected for the buffer signal.

\section{Cleavage activity}

Cleavage experiments were performed with Axygen agarose for electrophoresis connected to a Genei 50-500V power supply, visualized and photographed by the Vilber-INFINITY gel documentation system [22]. Cleavage experiments of supercoiled pBR322 DNA (300 mg) by compound $8(1.0-5.0 \mathrm{mM})$ in a $5 \mathrm{mM}$ Tris- $\mathrm{HCl} / 50 \mathrm{mM} \mathrm{NaCl}$ buffer at $\mathrm{pH} 7.2$ were carried out and the reaction followed by agarose gel electrophoresis. The sample was incubated at $37^{\circ} \mathrm{C}$ for $1 \mathrm{~h}$. A loading buffer, containing $25 \%$ bromophenol blue, $0.25 \%$ xylene cyanol and $30 \%$ glycerol, was added and electrophoresis was carried out at $60 \mathrm{~V}$ for $1 \mathrm{~h}$ in a Tris- $\mathrm{HCl}$ buffer using a $1 \%$ agarose gel containing $1.0 \mathrm{mg} / \mathrm{mL}$ of ethidium bromide. The reaction was also monitored upon addition of various radical inhibitors and/or activators such as DMSO, tert-butyl alcohol (TBA), sodium azide $\left(\mathrm{NaN}_{3}\right)$, superoxide dismutase (SOD), mercaptopropionic acid (MPA), glutathione (GSH), and $\mathrm{H}_{2} \mathrm{O}_{2}$.

\section{Molecular docking}

The rigid molecular docking studies were performed using HEX 6.1 software [23]. MGL tools 1.5.4 with AutoGrid4 and AutoDock4 were used to set up and exert blind docking calculations between the compound and DNA sequence. The compound 8 was taken for the following docking study. The crystal structure of the B-DNA dodecamer d (CGCAAATTTCGC) 2 (PDB ID: 1BNA) was downloaded from the protein data bank. All calculations were carried out on an Intel CORE i5, 3.1 GHz based machine running MS Windows XP as the operating system. First of all the heteroatoms including water molecules were deleted. The DNA was enclosed in a box with number of grid points in $\mathrm{x} \times \mathrm{y} \times \mathrm{z}$ directions, $76 \times 78 \times 120$ and a grid spacing of $0.375 \AA$ Lamarckian genetic algorithms, as accomplished in AutoDock, were employed to perform docking calculations. All other parameters were default settings. For each of the docking cases, the lowest energy docked conformation, according to the AutoDock scoring function, was selected as the binding mode. All calculations were carried out on 
Citation: Dar AM, Shamsuzzaman, Ahmad MS, Gatoo MA (2015) In Vitro DNA-Binding, Cleavage Activity with pbr322, Molecular Docking and Antiproliferative Studies of Newly Synthesized Steroidal Imidazolidine Hybrids. J Biomol Res Ther 4: 131. doi:10.4172/2167-7956.1000131

Page 3 of 9

an Intel CORE i5, 3.1 GHz based machine running MS Windows XP as the operating system. Visualization of the docked pose have been done using PyMol molecular graphics program [24].

\section{In vitro anticancer activity}

Cell culture and conditions: Human cancer cell lines A545 (lung carcinoma cells) / ATCC (CRL-2579), SW480 (colon adenocarcinoma cells) / ATCC (CCL-228), HeLa (cervical cancer cells) / ATCC (CCL-2), A549 (lung carcinoma cells) / ATCC (CCL-185), MCF7 (breast cancer cells) / ATCC (HTB-22), HepG2 (hepatic carcinoma cells) / ATCC (CRL-8065), HT-29 (colon cancer cells) / ATCC (HTB-38) and HL-60 (Leukaemia cells) / ATCC (CCL-240) were taken for the study. SW480, A549, HT-29, HL-60, A545 and HepG2 cells were grown in RPMI 1640 supplemented with $10 \%$ foetal bovine serum (FBS), 10U penicillin and $100 \mu \mathrm{g} / \mathrm{mL}$ streptomycin at $37^{\circ} \mathrm{C}$ with $5 \% \mathrm{CO}_{2}$ in a humidified atmosphere. HeLa and MCF7 cells were grown in Dulbecco's modified Eagle's medium (DMEM) supplanted with FCS and antibiotics.

Cell viability assay (MTT): The MTT assay was carried out according to known protocol [25]. Exponentially growing cells were harvested and plated in 96-well plates at a concentration of $1 \times 10^{4}$ cells/well. After $24 \mathrm{~h}$ incubation at $37^{\circ} \mathrm{C}$ under a humidified $5 \% \mathrm{CO}_{2}$ to allow cell attachment, the cells in the wells were respectively treated with target compounds, 5-Fluorouracil and Cisplatin at various concentrations for $48 \mathrm{~h}$. The concentration of DMSO was always kept below $1.25 \%$, which was found to be non-toxic to the cells. A solution of 3-(4,5-dimethylthiazo1-2-y1)-2,5-diphenyltetrazolium bromide (MTT), was prepared at $5 \mathrm{mg} / \mathrm{mL}$ in phosphate buffered saline (PBS; $1.5 \mathrm{mM} \mathrm{KH}_{2} \mathrm{PO}_{4}, 6.5 \mathrm{mM} \mathrm{Na}_{2} \mathrm{HPO}_{4}, 137 \mathrm{mM} \mathrm{NaCl}, 2.7 \mathrm{mM} \mathrm{KCl} ; \mathrm{pH}$ 7.4). $20 \mu \mathrm{L}$ of this solution was added to each well. After incubation for $4 \mathrm{~h}$ at $37^{\circ} \mathrm{C}$ in a humidified incubator with $5 \% \mathrm{CO}_{2}$, the medium/ MTT mixtures were removed, and the formazan crystals formed by the mitochondrial dehydrogenase activity of vital cells were dissolved in $100 \mu \mathrm{l}$ of DMSO per well. The absorbance of the wells was read with a microplate reader (Bio-Rad Instruments) at $570 \mathrm{~nm}$. Effects of the drug cell viability were calculated using cell treated with DMSO as control.

Data analysis: Cell survival was calculated using the formula: Survival $(\%)=[$ (absorbance of treated cells -absorbance of culture medium) / (absorbance of untreated cells - absorbance of culture medium) $] \times 100$ [26]. The experiment was done in triplicate and the inhibitory concentration (IC) values were calculated from a dose response curve. $\mathrm{IC}_{50}$ values were determined from the linear portion of the curve by calculating the concentration of agent that reduced absorbance in treated cells, compared to control cells, by $50 \%$.

\section{Comet assay}

To assess the genotoxic effect of the steroidal imidazolidines, comet assay [27] was performed in A549 cells. A549 $\left(1 \times 10^{6}\right)$ cells were treated with three different concentrations, 10,15 and $25 \mu \mathrm{g} / \mathrm{mL}$ of different steroid imidazolidine derivatives for $24 \mathrm{~h}$. The cells were then washed and $200 \mu \mathrm{L}$ of cell suspension in low melting Agarose (LMA) was layered on to the labelled slides precoated with Agarose $(1.5 \%)$. The slides were placed on ice for $10 \mathrm{~min}$ and submerged in lysis buffer $(2.5 \%$ $\mathrm{NaCl}, 100$ mM EDTA, 10 mM Tris, $10 \%$ DMSO and 1\% Troton X-100) at $\mathrm{pH} 10$ at $4^{\circ} \mathrm{C}$ for more than $1 \mathrm{~h}$. The slides were then equilibrated in alkaline buffer $\left(30 \mathrm{mM} \mathrm{NaOH}, 1 \mathrm{mM}\right.$ EDTA) at $\mathrm{pH} 13$ at $4^{\circ} \mathrm{C}$, electrophoresed at $0.86 \mathrm{~V} / \mathrm{cm}$ at $4^{\circ} \mathrm{C}$, neutralized, washed and dried. At the time of image capturing, the slides were stained with ethidium bromide $(\mathrm{EtBr}, 150 \mu \mathrm{L} 1 \mathrm{X})$ and cover slips were placed over them. For visualization of DNA-damage, EtBr stained slides were observed under
209 objectives of a fluorescent microscope (Olympus BX-51, Japan). The images of 50-100 randomly selected cells were captured per slide using a CCD camera.

\section{Western blot analysis}

MCF cells were grown on $100 \mathrm{~mm}$ tissue culture discs at a density of $1 \times 10^{6}$ cells per plate and incubated overnight. Then the cells were exposed to compound 8 and $9(0,15$ and $25 \mu \mathrm{M})$ for $48 \mathrm{~h}$ prior to harvest. The cell lysate was prepared by using modified RIPA lysis buffer ( $50 \mathrm{mM}$ tris, $150 \mathrm{mM} \mathrm{NaCl}, 0.5 \mathrm{mM}$ deoxycholate, $1 \% \mathrm{NP}-40$, $0.1 \%$ SDS, $1 \mathrm{mM} \mathrm{Na} \mathrm{VO}_{4}, 5 \mathrm{mM}$ EDTA, $1 \mathrm{mM}$ PMSF, $2 \mathrm{mM}$ DTT, $10 \mathrm{mM} \beta$-glycerophosphate, $50 \mathrm{mM}$ NAF, $0.5 \%$ triton X-100, protease inhibitor cocktail). Protein estimation was done by Bradford's method. Proteins were separated in 10\% SDS-PAGE and transferred to PVDF membrane. Membranes were blocked overnight in $10 \%$ skimmed milk in $1 \times$ TBS-T (Tris-buffered saline containing $0.05 \%$ of Tween-20) at $4^{\circ} \mathrm{C}$ and immunoblotted with antibodies anti-Bcl-XL, anti-Bax and anti-PARP. Detection of signals was done using ECL Western blotting reagent and chemiluminescence was exposed on Kodak X-Omat films. Antibody anti- $\beta$-actin was used as loading control. All the antibodies were procured from cell signalling technology, CA, USA.

\section{Result and Discussion}

\section{Chemistry}

The development of novel, potentially bioactive heterocyclic molecules has lead lot of focus on the research in synthesis of steroidal compounds in recent years, with the aim of obtaining new derivatives that may be of value in designing potentially anticancer active and DNA binding agents [28]. Hence we have envisioned the convenient synthesis of steroidal imidazolidines (7-9) from corresponding steroidal thiosemicarbazones (4-6) and ethyl-2-chloroacetoacetate in absolute ethanol (Scheme 1) and simultaneously study their DNA interaction behaviour and cytotoxicity. The synthesis of these steroidal imidazolidines is simple and does not demand rigorously dried solvents, reagents or inert atmosphere. The mechanism for the formation of compounds (7-9) involve the nucleophilic attack of the nitrogen of thiosemicarbazone on the carbonyl carbon of ethyl-2-chloroacetoacetate, making the ethoxy group to leave, with a simultaneous attack of another nitrogen on the chloro group of ethyl2-chloroacetoacetate, which leads to the formation of a imidazolidine heterocyclic moiety with a steroid skeleton.

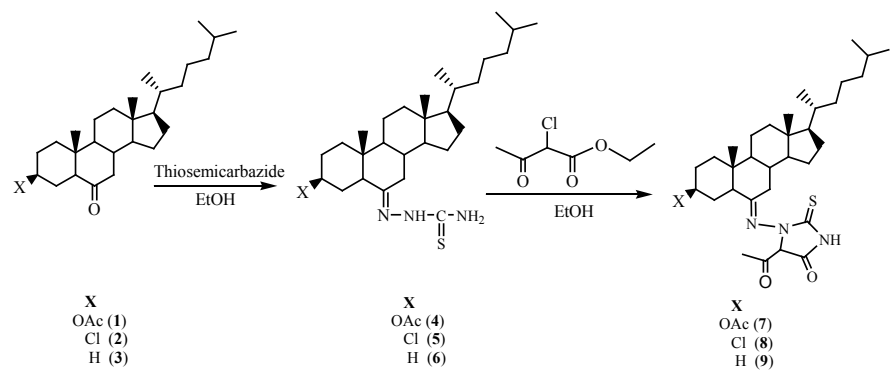

Scheme 1: Scheme showing the formation of steroidal imidazolidine derivatives

The characterization studies for structural elucidation of steroidal imidazolidines 7-9 included IR, ${ }^{1} \mathrm{H}$ NMR, ${ }^{13} \mathrm{C}$ NMR and MS. In the IR spectra, the strong absorption bands in the ranges 3327-3336, 16931695 and $1671-1674 \mathrm{~cm}^{-1}$ were attributed to the $\mathrm{NH}, \mathrm{CO}, \mathrm{CONH}$ groups, respectively while absorption bands at $1640-1643$ and $1267-1273 \mathrm{~cm}^{-1}$ 
Citation: Dar AM, Shamsuzzaman, Ahmad MS, Gatoo MA (2015) In Vitro DNA-Binding, Cleavage Activity with pbr322, Molecular Docking and Antiproliferative Studies of Newly Synthesized Steroidal Imidazolidine Hybrids. J Biomol Res Ther 4: 131. doi:10.4172/2167-7956.1000131

Page 4 of 9

confirmed the presence of the $\mathrm{C}=\mathrm{N}$ and $\mathrm{C}=\mathrm{S}$ group in compounds 7-9. In ${ }^{1} \mathrm{H}$ NMR study, the two singlets in the range $\delta 8.2-7.8$ and $4.42-4.41$ confirmed the presence of $\mathrm{NH}$ and $\mathrm{C}_{5}{ }^{\prime} \mathrm{H}$, respectively. In ${ }^{13} \mathrm{C}$ NMR study, the signals at $\delta 183-185,171-173,170-171,152-155$ confirmed the presence of the $C=\mathrm{S}, \mathrm{CONH}, \mathrm{C}=\mathrm{O}, \mathrm{C}=\mathrm{N}$ groups, respectively, in compounds 7-9. Finally, the presence of distinct molecular ion peaks $\left[\mathrm{M}^{+}\right]$at $\mathrm{m} / \mathrm{z} 599,575 / 577,541$, respectively in the MS spectra also proved the formation of compounds 7-9. This strategy can also be applied to diverse thiosemicarbazones; in that way imidazolidines may also allow further modifications on the substituted heterocyclic systems.

\section{DNA binding studies}

Electronic absorption titration: It is generally accepted that DNA is the primary pharmacological target of many antitumor agents. The binding activities of DNA-heterocycles have been a clue of paramount importance for understanding the mechanism of effective chemotherapeutic drugs. Absorption titration is usually used to determine the binding strength and the mode of DNA binding with small molecules [29]. Here in the UV-vis spectra of compounds (7-9) with increasing concentrations of CT DNA (Figure 1) which exhibited potential absorption bands at $288 \mathrm{~nm}$, attributed to the $\pi-\pi^{*}$ or intraligand transitions. Upon the addition of an increasing concentration of DNA $\left(0.70-4.24 \times 10^{-5} \mathrm{M}\right)$ to the compounds (7-9) in a $2 \% \mathrm{DMSO} / 5 \mathrm{mM}$ Tris $\mathrm{HCl} / 50 \mathrm{mM} \mathrm{NaCl}$ buffer solution, there was an increase in the absorption intensity of the intraligand absorption band (hyperchromism), without any shift of the position of the band. The hyperchromic effect is due to the electrostatic binding of the compound with the DNA base pairs by involving the hydrogen-bonding interaction between coordinated $-\mathrm{C}=\mathrm{O}$ with functional groups positioned on the edge of DNA bases, thereby causing the maximum exposure of base pairs to the light that leads to the increase in the absorption intensity hence the hyperchromism occurs [30]. These spectral studies reveal that compounds (7-9) exhibited higher binding propensity with DNA and interact presumably by electrostatic interaction via the phosphate backbone of the DNA double helix together with the hydrophobic interaction. The hydrophobic interaction with DNA replaces the water molecules in the DNA grooves, leading to an enhancement of the entropy and to the stabilization of the DNA-bound compound [31]. In order to further compare the binding strength of the compounds, their intrinsic binding constant $\left(\mathrm{K}_{\mathrm{b}}\right)$ were determined from the following equation (1) [32]

$$
[D N A] /\left|\varepsilon_{\mathrm{a}}-\varepsilon_{\mathrm{f}}\right|=[\mathrm{DNA}] /\left|\varepsilon_{\mathrm{b}}-\varepsilon_{\mathrm{f}}\right|+1 / \mathrm{K}_{\mathrm{b}}\left|\varepsilon_{\mathrm{b}}-\varepsilon_{\mathrm{f}}\right|
$$

Where, [DNA] is the concentration of DNA, $\varepsilon_{\mathrm{a}}, \varepsilon_{\mathrm{f}}$ and $\varepsilon_{\mathrm{b}}$ are apparent extinction coefficients $\mathrm{A}_{\text {obs }} /[\mathrm{M}]$, the extinction coefficient for free compound and the extinction coefficient for compound in the fully bound form, respectively. In the plots of [DNA] $/ \varepsilon_{\mathrm{a}}-\varepsilon_{\mathrm{f}}$ versus [DNA], $\mathrm{K}_{\mathrm{b}}$ is given by the ratio of the slope to the intercept.

The intrinsic binding constants for compounds (7-9) were found to be $2.07 \times 10^{4} \mathrm{M}^{-1}, 2.1 \times 10^{4} \mathrm{M}^{-1}$ and $1.9 \times 10^{4} \mathrm{M}^{-1}$, respectively hence the binding affinity follows the order $8>7>9$.

Fluorescence spectroscopy: The variety of molecular interactions such as excited state reactions, molecular rearrangements, energy transfer and collision are studied by fluorescent quenching techniques [33]. Here the fluorescence quenching experiments were undertaken to study the interaction of synthesized compounds (7-9) with CT DNA. The emission spectra of compounds (7-9) displayed intense luminescence at $358 \mathrm{~nm}$ at room temperature in the absence of DNA when excited at $290 \mathrm{~nm}$. On addition of increasing concentration of DNA $\left(0.70 \times 10^{-5}\right.$ to $\left.4.24 \times 10^{-5} \mathrm{M}\right)$ to the fixed amount of compounds $\left(1 \times 10^{-4} \mathrm{M}\right)$, the emission intensity appreciably increases (Figure 2$)$. The increase in the emission intensity is largely due to the extent to which the molecule is inserted into the hydrophobic environment of DNA minor groove. Also the hydrophobicity of DNA helix overcomes the solvent accessibility to the hydrophobic environment inside it and the compound mobility is restricted at the binding site, ultimately leading to a decrease in the vibrational mode of relaxation [34]. Furthermore, the binding of compound to the DNA helix could
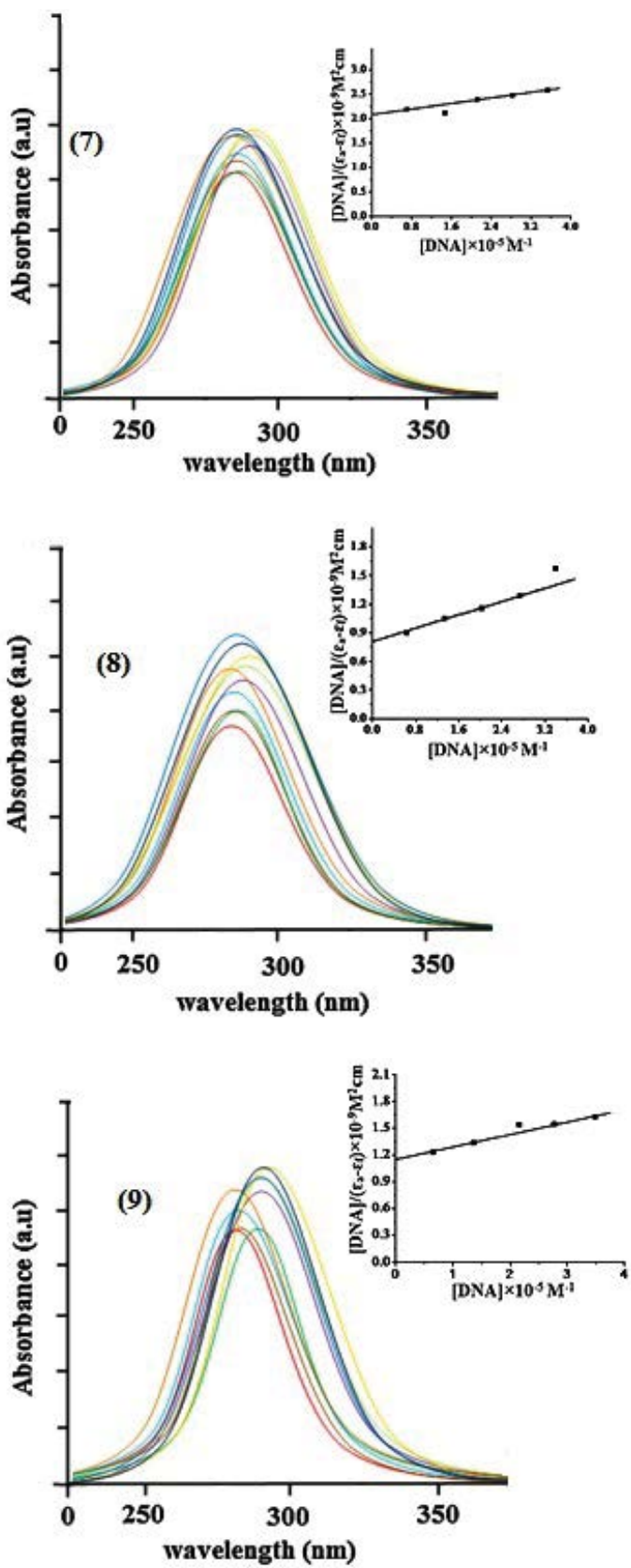

Figure 1: Absorption spectra of compounds (7-9) in Tris- $\mathrm{HCl}$ buffer upon the addition of calf thymus DNA [complex] $=6.67 \times 10^{-6} \mathrm{M}$, [DNA] $=0.70-4.24 \times$ $10^{-5} \mathrm{M}$. Arrow shows change in intensity with increasing concentration of DNA. 
Citation: Dar AM, Shamsuzzaman, Ahmad MS, Gatoo MA (2015) In Vitro DNA-Binding, Cleavage Activity with pbr322, Molecular Docking and Antiproliferative Studies of Newly Synthesized Steroidal Imidazolidine Hybrids. J Biomol Res Ther 4: 131. doi:10.4172/2167-7956.1000131

Page 5 of 9
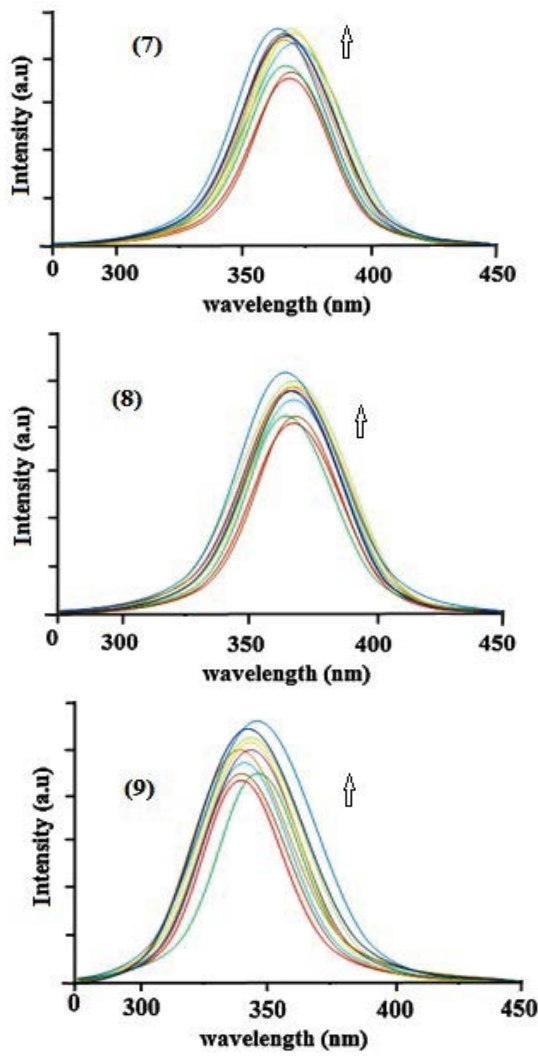

Figure 2: Emission spectra of compounds (7-9) in the presence of DNA in $5 \mathrm{mM}$ Tris- $\mathrm{HCl} / 50 \mathrm{mM} \mathrm{NaCl}$ buffer. Arrows show the intensity changes upon increasing concentration of the DNA.

decrease the collisional frequency of solvent molecules with the compound, leading to the emission enhancement of the compound. To compare the binding affinity of compounds to DNA quantitatively, the binding constant ' $K$ ' and binding site number ' $n$ ' were calculated by using Scatchard equation (2) and (3) $[35,36]$.

$$
\begin{aligned}
& C_{F}=C_{T}\left(F / F_{o}-P\right)(1-P) \\
& \mathbf{r} / \mathbf{c}=K(n-r)
\end{aligned}
$$

Where, $\mathrm{C}_{\mathrm{F}}$ is the concentration of free compound, $\mathrm{C}_{\mathrm{T}}$ is the total concentration of compound; $\mathrm{F}$ and $\mathrm{F}_{\mathrm{o}}$ are fluorescence intensities in the presence and absence of DNA, respectively. $\mathrm{P}$ is the ratio of observed fluorescence quantum yield of the bound compound to that of the free compound. The value $\mathrm{P}$ was obtained as the intercept by extrapolating from a plot of $\mathrm{F} / \mathrm{F}_{\mathrm{o}}$ versus 1 / [DNA], $r$ denotes the ratio of $\mathrm{C}_{\mathrm{B}}=\left(\mathrm{C}_{\mathrm{T}}-\mathrm{C}_{\mathrm{F}}\right)$ to the DNA concentration, ' $c$ ' is the free compound concentration and ' $n$ ' is the binding site number.

The binding constants for compounds (7-9) were calculated to be $2.7 \times 10^{4} \mathrm{M}^{-1}, 3.2 \times 10^{4} \mathrm{M}^{-1}$ and $2.4 \times 10^{4} \mathrm{M}^{-1}$, respectively. The number of steroid imidazolidines per DNA ' $n$ ' calculated [37] for (7-9) was found to be 1.13, 1.19 and 1.07, respectively indicating that compound 8 has higher DNA binding propensity in agreement with the absorption titration experiment.

The binding constant values are extracted from the (Figure 3 ) for compounds 7-9 with DNA and results (Table 1). From the binding constant, binding energies are calculated by equation (4):

$$
\Delta \mathrm{G}=-R T \operatorname{Ln} K(4)
$$

The negative value of $\mathrm{G}$ revealed the interaction of compounds 7-9 with DNA is favourable and follows the order $8>7>9$, which is in agreement with the absorption studies.

CD spectra: Since any particular variation of DNA conformation sensitizes the $C D$ signal hence the $C D$ spectroscopy is a quite sensitive technique to investigate the changes in DNA morphology and to determine mode of drug-DNA interactions [38]. In CD spectrum of B-DNA, the positive band is due to the base stacking $(277 \mathrm{~nm})$, while the negative one $(245 \mathrm{~nm})$ corresponds to the right-handed helicity [39]. In this study, the CD spectra of B-DNA were recorded in the presence of different molar ratios of the steroid compounds (7-9). The changes in the CD signals of B-DNA, as observed on the interaction with the compounds can be assigned to the corresponding changes in DNA morphology [40]. Classical intercalative molecules tend to enhance the intensities of bands due to strong base stacking interactions and stable DNA conformations, while simple groove binding and electrostatic interactions demonstrate less perturbation or no perturbation on the base stacking and helicity bands. Also it should be stated that intercalated compounds which disrupt interactions between DNA bases and weaken base stacking cause a decrease in the intensities of CD bands [38]. The CD spectra of DNA in the presence of the compounds (Figure 4).

The CD spectra of DNA with different values of the compound exhibit an increase in the positive peak and decrease in the negative band. These CD changes represent more stacking of DNA base pairs due to the hydrophobic interaction in groove region and decrease in the helicity of DNA by unwinding it. These compounds are assisting the electrostatic attraction with the DNA strand which can be followed by partial intercalation of their planar moieties between the base pairs in minor groove, allowing the interaction; therefore at the site of intercalation, DNA double helix can be unwound [41].

\section{Nuclease activity}

The DNA cleavage was controlled by the relaxation of supercoiled circular form of pBR322 DNA into the nicked and linear form. When

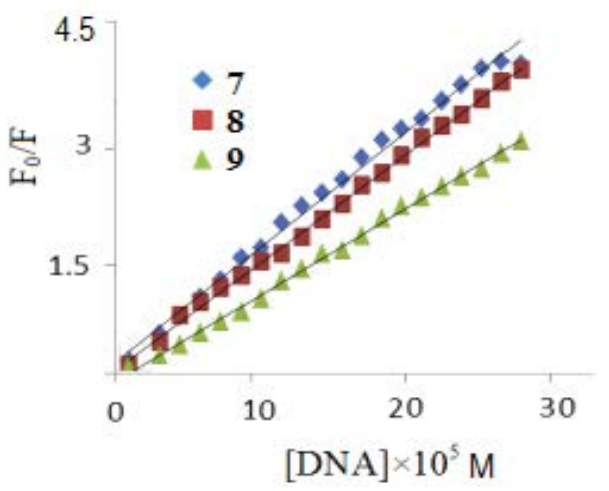

Figure 3: Stern-Volmer plots of the compounds (7-9) with DNA.

\begin{tabular}{|l|l|l|l|l|l|}
\hline & \multicolumn{3}{|l|}{ FLUORESCENCE } & \multicolumn{2}{l|}{ MOLECULAR DOCKING } \\
\hline Compound & $\mathrm{n}$ & $\mathrm{K}$ & $-\Delta \mathrm{G}(\mathrm{kJ} / \mathrm{mole})$ & $-\Delta \mathrm{G}(\mathrm{kJ} / \mathrm{mole})$ & $\mathrm{K}$ \\
\hline $\mathbf{7}$ & 1.13 & $2.7 \times 10^{4}$ & 343.72 & 333.68 & $2.2 \times 10^{4}$ \\
\hline $\mathbf{8}$ & 1.19 & $3.2 \times 10^{4}$ & 377.38 & 382.51 & $2.8 \times 10^{4}$ \\
\hline $\mathbf{9}$ & 1.11 & $2.4 \times 10^{4}$ & 363.51 & 355.83 & $2.1 \times 10^{4}$ \\
\hline
\end{tabular}

Table 1: Thermodynamic parameters like binding constant $K$ and free energy change $\Delta G$ obtained for the compounds 7-9 from fluorescence and molecular docking studies. 


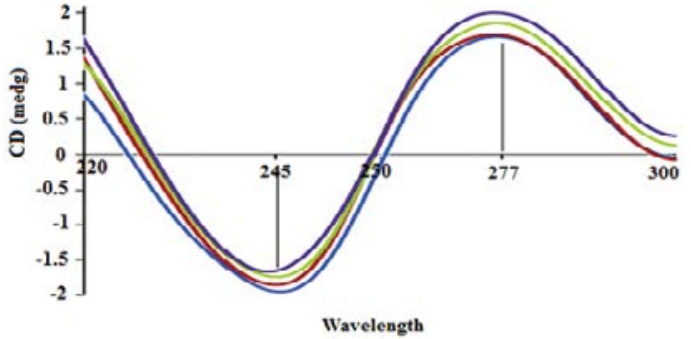

Figure 4: CD spectra of CT DNA (blue), in the presence of 7 (red), 8 (yellow) and 9 (violet).

a circular plasmid DNA is subjected to agarose gel electrophoresis, the fastest migration will be observed for supercoiled form (Form I). If one strand is cleaved, the supercoils will relax to produce a slower moving open circular form (Form II). If both strands are cleaved, a linear form (Form III) will be generated that migrates in between Form I and Form II. The DNA cleaving ability of compound 8 was investigated using pBR322 DNA. In the absence of any external additives the compound 8 cleaved double stranded supercoiled plasmid DNA (SC form: Form I) (300 mg) in $5 \mathrm{mM}$ Tris- $\mathrm{HCl} / 50 \mathrm{mM} \mathrm{NaCl}$ buffer into nicked circular form (NC form: Form II) after $1 \mathrm{~h}$ of incubation at physiological $\mathrm{pH} 7.2$ and temperature $25^{\circ} \mathrm{C}[42,43]$. Keeping the DNA concentration constant $(300 \mathrm{mg}$ ) the concentration of compound 8 was varied (1.0-5.0 $\mu \mathrm{M})$ and the cleavage reaction was further monitored by gel electrophoresis. The results revealed concentration-dependent electrophoretic cleavage clearly showing the conversion of SC form (Form I) to NC form (Form II) with increase in concentration of compound 8 .

At $4 \mu \mathrm{M}$ concentration (Lane 5), compound 8 exhibited efficient nuclease activity. At still higher concentrations there was complete conversion of SC form into NC form with the concurrent formation of LC form. Presence of Form I, II, and III of pBR322 DNA indicated that compound 8 is involved in double strand DNA cleavage (Figure 5).

The nuclease activity in the presence of activators viz; MPA, GSH and $\mathrm{H}_{2} \mathrm{O}_{2}$ were also observed and the results showed significant enhancement in the cleavage activity. Their activating efficacy follows the order of $\mathrm{GSH}=\mathrm{H}_{2} \mathrm{O}_{2}>$ MPA. To predict the mechanism of $\mathrm{pBR} 322$ plasmid DNA cleavage by compound 8 , comparative experiments were carried out in the presence of various radical inhibitors or trappers such as singlet oxygen scavenger sodium azide $\left(\mathrm{NaN}_{3}\right)$, hydroxyl radical scavengers viz.; dimethylsulfoxide (DMSO), $t$-butyl alcohol (TBA) and superoxide dismutase (SOD) as superoxide anion inhibitor (Figure 6). When the hydroxyl radical scavenger DMSO and TBA were added to the reaction mixture the nuclease activity was not inhibited, excluding the role of hydroxyl radical in the cleavage process. In the presence of radical scavengers like $\mathrm{NaN}_{3}$ and SOD, the cleavage was significantly inhibited under the present experimental conditions. Therefore, the compound 8 seems to follow the mechanistic pathway involving singlet oxygen and superoxide anion to generate ROS responsible for initiating DNA strand scission [44].

\section{DNA cleavage in the presence of minor and major groove binders}

DNA recognition elements (groove binding) DAPI (minor groove binding) [45] and methyl green (major groove binding) [46] were used to probe the potential interacting site of compound 8 with supercoiled pBR322 DNA. (Figure 7), upon the addition of DAPI (Lane 2), there is apparent inhibition of the cleavage activity of 8 suggesting that the compound is a minor groove binder which is in conformity with many literature reports revealing that imidazolidine derivatives play important roles in several DNA minor groove binding agents such as Hoechst 33258 and Hoechst 33342 [47, 48].

\section{Molecular docking}

To understand steroidal imidazolidine-DNA interaction, the molecular docking technique is an attractive tool to get insight of the mechanistic study, by placing a molecule into the binding site of the target specific region of the DNA. In our experiment, rigid molecular docking (two interacting molecules were treated as rigid bodies) studies were performed with HEX 6.1 software [23] to predict the binding modes of compounds with a DNA duplex of sequence $d$ (CGCAAATTTCGC) ${ }_{2}$ dodecamer (PDB ID: 1BNA), and provide an energetically favourable docked structures (DNA-compound 8 shown in Figure 8). It is evident from the figure that these type of compounds gets attached with DNA through minor groove and their imidazolidine moiety shows intercalation between the nucleotide base pairs of DNA. The docked complex of steroidal imidazolidine and DNA (Figure 8) depicts that the oxygen (of carbonyl group) of the imidazolidine ring forms a hydrogen bond with the $2^{\text {nd }}$ nitrogen of $4^{\text {th }}$ guanine of DNA. In this configuration, the group at $3 \beta$-axial position (i.e., X-moiety) remains inclined towards the phosphodiester bond of DNA and the possibility of hydrogen bonding cannot be ruled out. Since the changes in accessible surface area of interacting residues show a preferential binding of compound between G-C base pairs and bends the DNA

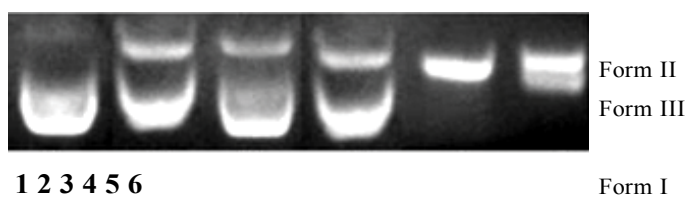

Figure 5: Agarose gel electrophoresis patterns of pBR322 plasmid DNA $(300 \mathrm{mg})$ cleaved by compound $8(1.0-5.0 \mu \mathrm{M})$, after $1 \mathrm{~h}$ incubation time (concentration dependent) Lane 1: control; Lane 2: $1.0 \mu \mathrm{M} 8$ + DNA; Lane 3: $2.0 \mu \mathrm{M} 8$ + DNA; Lane 4: 3.0 $\mu \mathrm{M}$ 8 + DNA. Lane 5: $4.0 \mu \mathrm{M} 8$ + DNA; Lane 6: 5.0 $\mu \mathrm{M} 8+\mathrm{DNA}$, in buffer $\left(5 \mathrm{mM}\right.$ Tris- $\mathrm{HCl} / 50 \mathrm{mM} \mathrm{NaCl}, \mathrm{pH} 7.2$ at $\left.25^{\circ} \mathrm{C}\right)$.

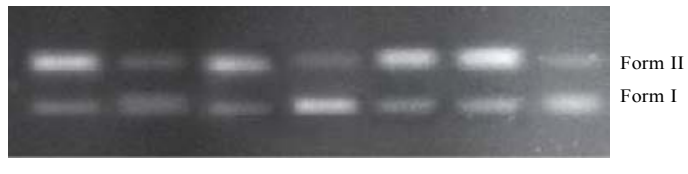

1234567

Figure 6: Agarose gel electrophoresis pattern for the cleavage of pBR322 supercoiled DNA (300 mg) by compound $8(2.0 \mu \mathrm{M})$ in presence of different activating agents and radical scavengers Lane 1: $8+\mathrm{GSH}+\mathrm{DNA}$. Lane 2: 8 + MPA + DNA. Lane 3: $8+\mathrm{H}_{2} \mathrm{O}_{2}+$ DNA. Lane 4: $8+\mathrm{NaN}_{3}+$ DNA. Lane 5: $8+$ DMSO + DNA. Lane 6: $8+t$-butyl alcohol + DNA. Lane 7: $8+$ SOD + DNA in buffer $\left(5 \mathrm{mM}\right.$ Tris- $\mathrm{HCl} / 50 \mathrm{mM} \mathrm{NaCl}, \mathrm{pH} 7.2$ at $\left.25^{\circ} \mathrm{C}\right)$.

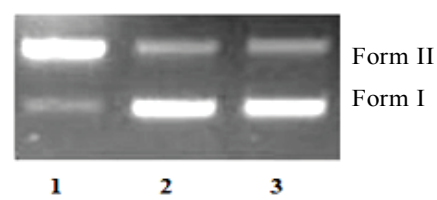

Figure 7: Agarose gel electrophoresis pattern for the cleavage of pBR322 plasmid DNA $(300 \mathrm{mg})$ by $8(0.25 \mathrm{mmol})$ Lane 1 , DNA $+8+$ methyl green (major groove binding agent); Lane 2, DNA + 8 + DAPI (minor groove binding agent) (8 mM); Lane 3; DNA control $(2.5 \mathrm{~mL}$ of $0.01 \mathrm{mg} / \mathrm{mL}$ solution) at $310 \mathrm{~K}$ after incubation for $45 \mathrm{~min}$. 
Citation: Dar AM, Shamsuzzaman, Ahmad MS, Gatoo MA (2015) In Vitro DNA-Binding, Cleavage Activity with pbr322, Molecular Docking and Antiproliferative Studies of Newly Synthesized Steroidal Imidazolidine Hybrids. J Biomol Res Ther 4: 131. doi:10.4172/2167-7956.1000131

Page 7 of 9

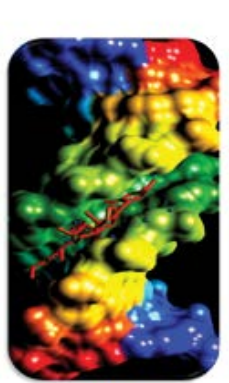

(A)

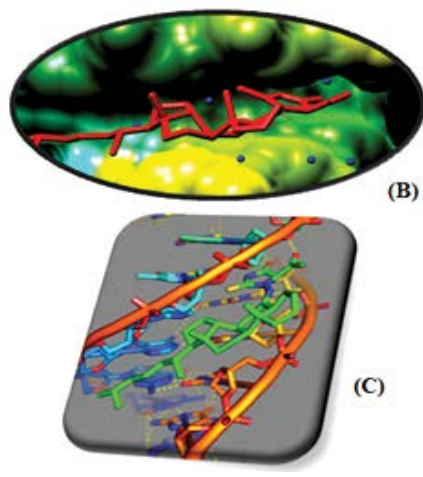

(B)

C)
Figure 8: Cartoon representation of DNA-Compound. The $\mathrm{N}, \mathrm{S}$ and the $\mathrm{O}$ termini of the imidazolidine moiety of compound are shown $(\mathrm{C})$ as blue, yellow and red sticks, respectively. (a), (b) and (c) show minimum energy poses of DNA-Steroidal imidazolidine complex.

slightly in such a way that a part of the molecule comes between the two base pairs of the minor groove of DNA helix which makes favourable stacking interactions between the ring systems of the DNA bases and the imidazolidine ring of compound. The resulting relative binding energy of docked steroidal imidazolidine-DNA complexes was found to be -333.68 to $-382.51 \mathrm{~kJ} \mathrm{~mol}^{-1}$ (Table 1). This value is consistent with the high binding constant obtained from spectroscopic values.

Although the binding energy calculated from docking simulation for the DNA compound complexes are slightly higher than the experimental free energy of binding obtained from the fluorescence data. The slight discrepancy in the free energy change is attributed to the rigidity of DNA in the molecular docking studies or exclusion of the solvent molecules.

\section{In vitro cytotoxicity}

This activity was measured using the 3-(4,5-dimethylthiazol2-yl)-2,5-diphenyltetrazolium bromide (MTT) assay during which the conversion of the soluble yellowish MTT to the insoluble purple formazan by active mitochondrial lactate dehydrogenase of living cells has been used to develop an assay system for measurement of cell proliferation [25]. The data reported in Table 2 suggests that compounds showed different levels of cytotoxicity. Since literature reveals that thiosemicarbazone derivatives have been found potentially active against different cancer cells [49] hence with this intuition, in vitro anticancer activity of thiosemicarbazone derivatives was carried out using the MTT assay. During the cytotoxic screening almost all the steroidal imidazolidines depicted potential anticancer behaviour against given cancer cells by showing less inhibition count but compound 7 and 8 showed much effective IC $_{50}=6.81 \mu \mathrm{M}$ and $5.17 \mu \mathrm{M}$ against HL-60 cell line. The compound 7 and 8 also showed potential $\mathrm{IC}_{50}=7.73 \mu \mathrm{M}$ and $7.24 \mu \mathrm{M}$ against MCF-7 cell line. The compound 8 and 9 also depicted promising behaviour against A549 cell line by showing $\mathrm{IC}_{50}=7.43$ and $6.29 \mu \mathrm{M}$, respectively.

The overall cytotoxicity of these compounds may be attributed to the more hydrophilicity and more bioavailability of the imidazolidine derivatives.

Microscopic examination of gross morphology of cancer cells and comparison with imidazolidine treated cancer cells (Figure 9). The HL60 cell line when treated with $8(5.17 \mu \mathrm{M})$ the growth was inhibited within $24 \mathrm{~h}$ and the cells were almost completely dead after $36 \mathrm{~h}$. Same behaviour was shown by lung carcinoma (A549) cell line when treated with $8(7.43 \mu \mathrm{M})$ and within $24 \mathrm{~h}$ the growth inhibited but after $36 \mathrm{~h}$, the A549 cancer cells were almost dead.

\section{Comet assay}

In the comet assay [27], the images of cells treated with Cisplatin and compounds 8 and 9 showed the formation of comets. No comet pattern was observed in the control cells. There was dose-dependent increase in tail length when treated with compounds 7-9 (Figure 10). Compound 8 and 9 presented maximum apoptotic DNA damage among the three steroidal imidazolidines studied. None of the steroidal imidazolidine exhibited apoptotic DNA damage to the extent of Cisplatin. The increase in DNA damage suggested that compounds derivatives induced dose-dependent fragmentation of chromosomal DNA leading to apoptosis. The images of comet assay for control, cells treated with Cisplatin $(50 \mu \mathrm{g} / \mathrm{mL}), 7(50 \mu \mathrm{g} / \mathrm{mL}), 8(50 \mu \mathrm{g} / \mathrm{mL})$ and 9 $(50 \mu \mathrm{g} / \mathrm{mL})$ are shown in Figure 10. Slides were analysed for parameter like tail length (TL), using image analyzer CASP software version 1.2.2. The results of the assay for tail length (Figure 11).

\section{Western blot analysis}

To confirm the apoptotic effect of compound 8 and 9 in A549 cells, a study of protein levels of some apoptotic markers such as Caspase-3, Bax, Bcl-XL and PARP cleavage was performed by Western blot analysis (Figure 12). The expression of Bcl-XL was reduced when cells were exposed to compound 8 and 9 of increasing concentrations $(0,15$ and $25 \mu \mathrm{M})$. In contrast to Bcl-XL, the expression of Bax and Caspase-3 was increased. The level of cleaved PARP product $(104 \mathrm{KDa})$ was higher

\begin{tabular}{|l|l|l|l|l|l|l|l|l|}
\hline IC50 $(\boldsymbol{\mu M})$ & $\mathbf{9}$ \\
\hline Comp. & Lung & $\begin{array}{l}\text { Breast } \\
\text { A545 }\end{array}$ & $\begin{array}{l}\text { Cervical } \\
\text { HeLa }\end{array}$ & $\begin{array}{l}\text { Leukaemia } \\
\text { HL-60 }\end{array}$ & $\begin{array}{l}\text { Colon } \\
\text { SW480 }\end{array}$ & $\begin{array}{l}\text { Hepatic } \\
\text { HepG2 }\end{array}$ & $\begin{array}{l}\text { Colon } \\
\text { HT-29 }\end{array}$ & $\begin{array}{l}\text { Lung } \\
\text { A549 }\end{array}$ \\
\hline 4 & 29.46 & 22.17 & 37.77 & 45.29 & 19.26 & 34.12 & 26.73 & 33.18 \\
\hline 5 & 26.28 & 17.62 & 39.25 & 43.21 & $>50$ & 30.51 & 35.97 & 41.32 \\
\hline 6 & 18.23 & 34.58 & 33.68 & $>50$ & 29.52 & 26.72 & 38.23 & 29.66 \\
\hline 7 & 10.11 & 7.73 & 10.72 & 6.81 & 11.37 & 7.93 & 13.88 & 9.33 \\
\hline 8 & 7.67 & 7.24 & 9.23 & 5.17 & 10.33 & 9.37 & 8.63 & 7.43 \\
\hline 9 & 8.41 & 10.13 & 11.91 & 7.79 & 9.11 & 10.26 & 8.12 & 6.29 \\
\hline Cisplatin & 8.9 & 9.3 & 9.43 & 7.83 & 3.52 & 9.80 & 7.24 & 12.0 \\
\hline 5-FU & 15.4 & 15.3 & 16.32 & 12.45 & 15.71 & 11.31 & 9.79 & 12.8 \\
\hline 5-FU = 5-Fluorouracil & & & & & & \\
\hline
\end{tabular}

Table 2: The $I C_{50}$ values shown by compounds $4-9$, Cisplatin and 5-Fu agains given cancer cell lines.
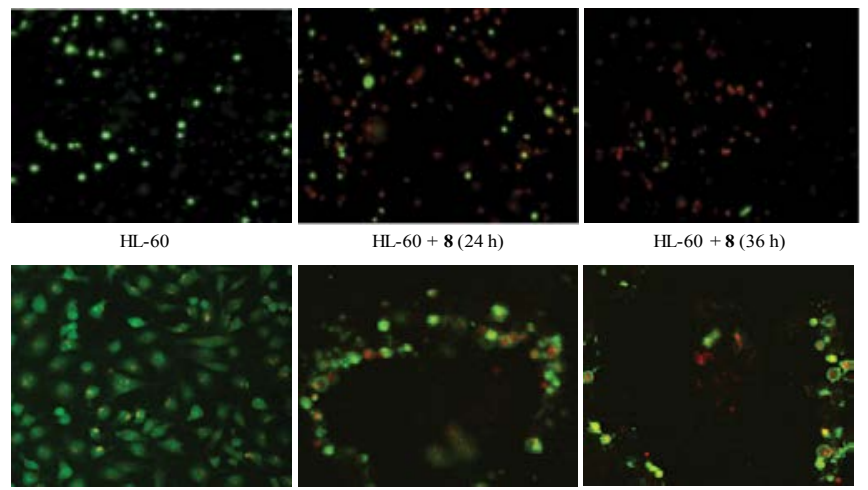

$\mathrm{HL}-60+\mathbf{8}(24 \mathrm{~h})$

$\mathrm{HL}-60+8(36 \mathrm{~h})$
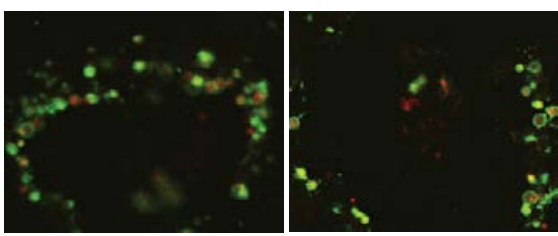

A5 $49+8(24$ h $)$

$\mathrm{A} 549+\mathbf{8}(36 \mathrm{~h})$

Figure 9: Microscopic examination of the interaction of HL-60 and A549 cancer cells with steroidal imidazolidine 8 . 
Citation: Dar AM, Shamsuzzaman, Ahmad MS, Gatoo MA (2015) In Vitro DNA-Binding, Cleavage Activity with pbr322, Molecular Docking and Antiproliferative Studies of Newly Synthesized Steroidal Imidazolidine Hybrids. J Biomol Res Ther 4: 131. doi:10.4172/2167-7956.1000131

Page 8 of 9

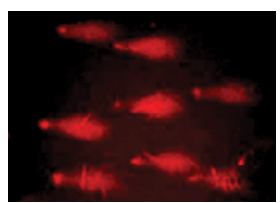

$\mathrm{A} 549+\mathbf{8}$

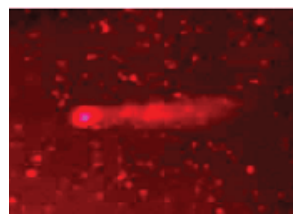

A549 + Cisplatin

Figure 10: Detection of DNA damage in A549 cells. Treated cells (24 h) were layered over agarose gel, lysed, electrophoresed in alkaline buffer and stained with propidium iodide. Control cells were treated with DMSO alone.

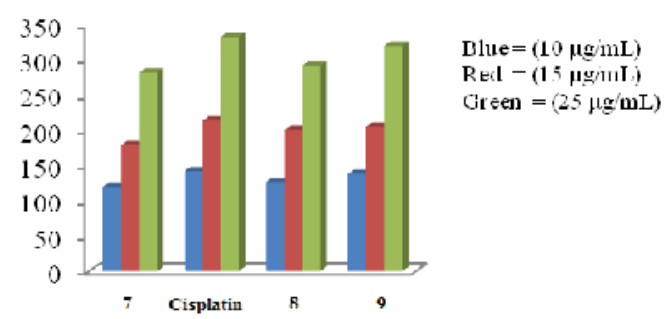

Figure 11: Graph comparing the effect of steroidal imidazolidines on the tai length in comet assay. There was a concentration-dependent increase in the apoptotic DNA fragmentation and hence an increase in tail length in all three imidazolidine derivatives.

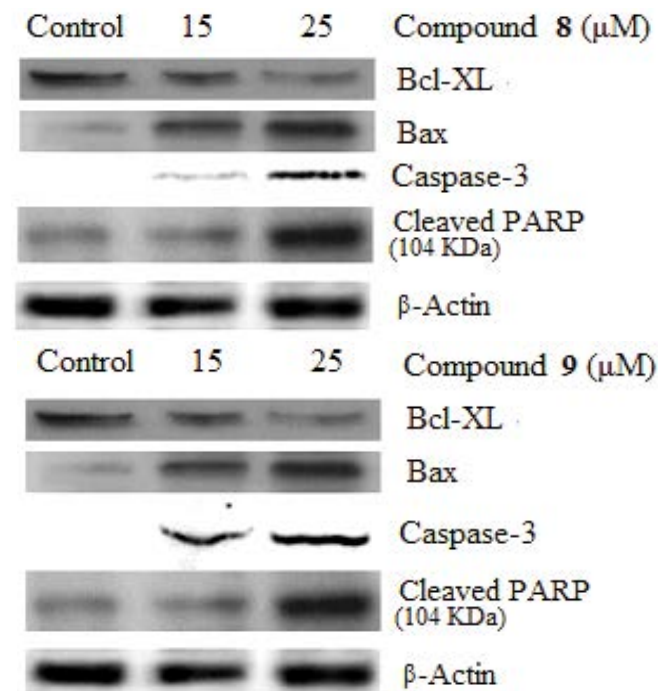

Figure 12: Western blot analysis of whole cell extracts. Lower panel ( $\beta$-actin) represent equal loading of each lane.

in the treated cells than untreated cells and increased with increasing concentrations of the compound 8 and 9 . As expected, the expression of $\beta$-actin, which served as a loading control, remained unaltered. These relative expressions of relevant apoptotic markers including the increasing Bax/Bcl-XL ratio, Caspase- 3 and PARP cleavage clearly indicate that imidazolidines 8 and 9 cause apoptosis in MCF-7 cancer cells.

\section{Conclusion}

In summary the development and operationally designed simple strategy for the better synthesis of steroidal imidazolidines was successful. Absorption and fluorescence studies reveal the stabilization of the energy levels of the compounds in presence of DNA. The cleavage and molecular docking studies undertaken in the present work are in total agreement with the primary intercalative mode of binding, although the van der Waals and other types of interactions can also be argued. From in vitro cytotoxicity screening, it is clear that steroidal imidazolidines were found to be potential cytotoxic agents in comparison with standard drugs, Cisplatin and 5-Flu. Potential apoptic and genotoxic nature of compounds was depicted by western blotting and comet assay, respectively. Hence, the present study has shown that these synthesized compounds can be used as template for future development through modification and derivatization to design more potent and selective cytotoxic agents.

\section{Acknowledgements}

Authors thank Department of Chemistry and Biochemistry (JNMC), AMU Aligarh, for providing research facilities and biological results. Authors thank specially Prof. Shamsuzzaman for useful discussions and for successful completion of this work.

\section{References}

1. Newman DJ, Cragg GM (2007) Natural products as sources of new drugs over the last 25 years. J Nat Prod 70: 461-477.

2. Bellina F, Cauteruccio S, Rossi R (2007) Synthesis and biological activity of vicinal diary -substituted 1H-imidazoles. Tetrahedron 63: 4571-4624.

3. Bolani M, Gonzalez M (2005) Imidazole and benzimidazole derivatives as chemotherapeutic agents. Mini Rev Med Chem 5: 409-424

4. Salerno L, Sorrenti V, Guerrera F (1999) N-substituted-imidazoles as inhibators of nitric oxide synthase: a prelimnary screening. Pharmazie 54: 685-690.

5. Husain A, Ahmad A, Al-Abbasi FA (2015) Synthesis, molecular properties, toxicity and biological evaluation of some new substituted imidazolidine derivatives in search of potent anti-inflammatory agents. Saudi Pharmaceutica Journal.

6. Marki F, Buch O, Delini-Stula A, Kraetz J, Petermann H, et al. (1984) Sulfonyliminoimidazolidines, a new class of oral hypoglycemic agents, Toxicity and general pharmacology of 1-[p-[2-(crotonylamino)-ethyl]-phenylsulfonyl]3-cyclohexy I-2-imino-imidazolidine (CGP 11 112). Arzneimittelforschung 34 247-252.

7. Sharma V, Khan MS (2001) Synthesis of novel tetrahydroimidazole derivatives and studies for their biological properties. Eur J Med Chem 36: 651-658.

8. Caterina MC, Perillo IA, Boiani L, Pezaroglo $\mathrm{H}$, Cerecetto $\mathrm{H}$, et al. (2008) Imidazolidines as new anti-Trypanosoma cruzi agents: biological evaluation and structure activity relationships. Bioorg Med Chem 16: 2226-2234

9. Saczewski J, Hudson AL, Rybczynska A (2009) 2-[(arylmethoxy)imino] imidazolidines with potential biological activities. Acta Pol Pharm 66: 671-679.

10. Robert JG, Daryl SW, Paul JB, Elena F, Anton DM, et al. (2010) Synthesis and biological activity of a series of tetrasubstituted-imidazoles as P2X 7 antagonists. Bioorg Med Chem Lett 20: 4951-4954.

11. Patel MV, Bell R, Majest S, Henry R, Kolasa T (2004) Synthesis of 4, 5-Diaryl$1 \mathrm{H}$-pyrazole-3-ol derivatives as potential COX-2 inhibitors. J Org Chem 69 7058-7065.

12. Mantovani A, Pierotti MA (2008) Cancer and inflammation: a complex relationship. Cancer Lett 267: 180-181.

13. El-Sonbati AZ, Shoair AF, El-Bindary AA, Diab MA, Mohamed AS (2015) Synthesis, characterization, DNA binding and catalytic activities of $\mathrm{Ru}(\mathrm{III})$ complexes. J Mol Liq 209: 635-647.

14. Sigman DS, Mazumder A, Perrin DM (1993) Chemical nucleases. Chem Rev 93: $2295-2316$

15. Shoair AF, El-Shobaky AR, Azab EA (2015) Synthesis, characterization, DNA binding and catalytic applications of Ru(III) complexes. Spectrochim Acta A Mo Biomol Spectrosc 151: 322-334. 
Citation: Dar AM, Shamsuzzaman, Ahmad MS, Gatoo MA (2015) In Vitro DNA-Binding, Cleavage Activity with pbr322, Molecular Docking and Antiproliferative Studies of Newly Synthesized Steroidal Imidazolidine Hybrids. J Biomol Res Ther 4: 131. doi:10.4172/2167-7956.1000131

16. Smith J, Ariga K, Anslyn EV (1993) Enhanced imidazole-catalyzed RNA cleavage induced by a bis-alkyl guanidinium receptor. J Am Chem Soc 115: 362-364

17. Scheffer U, Strick A, Ludwig V, Peter S, Kalden E, et al. (2005) Metal-free catalysts for the hydrolysis of RNA derived from guanidines, 2-aminopyridines, and 2-amino benzimidazoles. J Am Chem Soc 127: 2211-2217.

18. Shamsuzzaman, Dar AM, Khan Y, Sohail A (2013) J. Photochem. Photobiol. B: Biology 129: 36-47.

19. Son GS (1998) Binding mode of norfloxacin to calf thymus DNA. J Am Chem Soc 120: 6451-6457.

20. Shamsuzzaman, Salim A, Aslam M, Naqvi F (1997) Synthesis of Steroidal Spiro-1',2',4'-triazolidine-3'-thiones. Synth Commun 27: 2171-2175.

21. Reicmann ME, Rice SA, Thomas CA, Doty PA (1954) A furhter examination of the molecular weight and size of deoxy pentose nucleic acid. J Am Chem Soc 76: $3047-3053$

22. Budagumpi S, Kulkarni NV, Kurdekar GS, Sathisha MP, Revankar VK (2010) Eur J Med Chem 45: 455-462.

23. Mustard D, Ritchie DW (2005) Docking essential dynamics eigen structures, Proteins: Struct Funct Bioinf 60: 269-274.

24. Delano WL (2002) The PyMOL Molecular Graphics System, DeLano Scientific San Carlos, CA, USA.

25. Mosmann T (1983) Rapid colorimetric assay for cellular growth and survival: application to proliferation and cytotoxicity assays. J Immunol Methods 65: 5563.

26. Saxena HO, Faridi U, Kumar JK, Luqman S, Darokar MP, et al. (2007) Synthesis of chalcone derivatives on steroidal framework and their anticance activities. Steroids 72: 892-900.

27. Singh NP (2000) Microgels for estimation of DNA-strand breaks, DNA protein crosslinks and apoptosis. Mut Res 455: 111-127.

28. Kaminskyy D, Bednarczyk-Cwynar B, Vasylenko O, Kazakova O, Zimenkovsky $B$, et al. (2012) Synthesis of new potential anticancer agents based on 4-thiazolidinone and oleanane scaffolds. Med Chem Res 21: 3568-3580.

29. Wang BD, Yang ZY, Crewdson P, Wang DQ (2007) Synthesis, crystal structure and DNA -binding studies of the Ln(III) complex with 6- hydroxychromone-3carbaldehyde benzoyl hydrazone. J Inorg Biochem 101: 1492-1504.

30. Shahabadi N, Kashanian S, Khosravi M, Mahdavi M (2010) Multispectroscopic DNA interaction studies of a water-soluble nickel(II) complex containing different dinitrogen aromatic ligands. Trans Metal Chem 35: 699-705.

31. Berk AJ (2000) TBP-like factors come into focus. Cell 103: 5-8.

32. Wolfe A, Shimer GH, Meehan T (1987) Polycyclic aromatic hydrocarbons physically intercalate into duplex regions of denatured DNA. Biochemistry 26 : 6392-6396.

33. Eftink MR (1991) Fluorescence Quenching Reaction: Probing Biological Macromolecular Structures, Biophysical and Biochemical Aspects of Fluorescence Spectroscopy. Plenum Press, New York.
34. Tan LF, Chao H, Zhen KC, Fei JJ, Wang F, et al. (2007) Effects of the ancillary ligands of polypyridyl ruthenium(II) complexes on ther DNA binding and photocleavage behaviours. Polyhedron 26: 5458-5468.

35. Scatchard G (1949) The attractions of proteins for small molecules and ions Ann NY Acad Sci 51: 660-672.

36. Lakowiez JR, Webber G (1973) Quenching of fluorescence by oxygen. A probe for structural fluctuations in macromolecules. Biochemistry 12: 4161-4170.

37. Charbonneau D, Beauregard M, Tajmir-Riahi HA (2009) Structural analysis of Human Serum Albumin complexes with cationic lipids. J Phys Chem B 113 1777-1784.

38. Nejat Dehkordi M, Bordbar AK, Lincoln P, Mirkhani V (2012) Spectroscopic study on the interaction of ct-DNA with manganese salen complex containing triphenyl phosphonium groups. Spectrochim Acta A 90: 50-54.

39. Maheswari PU, Palaniandavar M (2004) DNA binding and cleavage properties of certain tetrammine ruthenium (II) complexes of modified 1,10-phenonthrolineseffect of hydrogen bonding on DNA-binding affinity. J Inorg Biochem 98: 219230.

40. Lincoln P, Tuite E, Nordén B (1997) Short circuiting the molecular wirecoperative binding of $\Delta-[\mathrm{Ru}(\mathrm{Phen}) 2 \mathrm{dppz}] 2+$ and $\Delta-[\mathrm{Rh}($ phi)2Bipy $] 3+$ to DNA. J Am Chem Soc 119: 1454-1455.

41. Lepre C, Lippard S, Eckstein F, Lilley DMJ (1990) Eds., Nucleic Acids and Molecular Biology, Springer, Germany 4: 9-38.

42. Rajendiran V, Murali M, Suresh E, Palaniandavar M, Periasamy VS, et al (2008) Non-covalant DNA binding and cytotoxicity of certain mixed ligand ruthenium(II) complexes of 2,2-dipyridylamine and diamines. Dalton Trans 16 2157-2170.

43. Ramakrishnan S, Rajendiran V, Palaniandavar M, Periasamy VS, Srinag BS, et al. (2009) Induction of cell death by ternary $\mathrm{Cu}(\mathrm{II})$ complexes of I-tyrosine and diimines: role of coligands on DNA binding and cleavage and anticancer activity. Inorg Chem 48: 1309-1322.

44. Westheimer FH (1987) Why nature chose phosphates, Science 235: 1173 1178.

45. Trotta E, Del G, Erba N, Paci M (2000) The ATT strand of ATT. ATT trinucleotide repeats adopts stable hairpin structures induced by minor groove binding ligands. Biochemistry 39: 6799-6808.

46. Wittung $P$, Nielsen $P$, Norden B (1996) Direct observation of strand invasion by peptide nucleic acid (PNA) into double stranded DNA. J Am Chem Soc 118: 7049-7054.

47. Bailly C, Chessari G, Carrasco C, Joubert A, Mann J, et al. (2003) Sequence specific minor groove binding by bis-benzimidazoles: water molecules in ligand recognition. Nucleic Acids Res 31: 1514-1524.

48. Smith CEB, Searle MS (1999) Sequence dependent variation in DNA minor groove width dictates orientational preference of Hoechst 33258 in A-tract recognition: solution NMR structure of the 2:1 complex with d(CTTTTGCAAAAG) $)_{2}$, Nucleic Acids Res 27: 1619-1624

49. Zhang HJ, Qian Y, Zhu DD, Yang XG, Zhu HL (2011) Synthesis, molecular modelling and biological evaluation of chalcone thiosemicarbazide derivatives as novel anticancer agents. Eur J Med Chem 46: 4702-4708. 